\title{
Agroecologically efficient agricultural systems for smallholder farmers: contributions to food sovereignty
}

\author{
Miguel A. Altieri • Fernando R. Funes-Monzote • \\ Paulo Petersen
}

Accepted: 21 November 2011 /Published online: 14 December 2011

(C) The Author(s) 2011. This article is published with open access at Springerlink.com

\begin{abstract}
The realization of the contribution of peasant agriculture to food security in the midst of scenarios of climate change, economic and energy crisis, led to the concepts of food sovereignty and agroecologically based production systems to gain much attention in the developing world in the last two decades. New approaches and technologies involving application of blended modern agricultural science and indigenous knowledge systems and spearheaded by thousands of farmers, NGOs, and some government and academic institutions are proving to enhance food security while conserving agrobiodiversity soil and water resources conservation throughout hundreds of rural communities in the developing world. Case studies from Cuba, Brazil, Philippines, and Africa are presented to demonstrate how the agroecological development paradigm based on the revitalization of small farms which emphasizes diversity, synergy, recycling and integration, and social processes that value community participation and empowerment, proves to be perhaps one of the only viable options to meet present and future food needs. Given the present and predicted near future climate, energy and economic scenarios, agroecology has emerged as one of the most robust pathways towards designing biodiverse, productive, and resilient agroecosystems available today.
\end{abstract}

M. A. Altieri $(\bowtie)$

University of California,

Berkeley, CA, USA

e-mail: agroeco3@berkeley.edu

F. R. Funes-Monzote

Estación Experimental Indio Hatuey, Universidad de Matanzas,

Matanzas, Cuba

P. Petersen

AS-PTA,

Rio de Janeiro, Brazil
Keywords Agroecology · Production systems .

Agrobiodiversity $\cdot$ Food sovereignity $\cdot$ Smallholder farmers

Contents

1. Introduction . . . . . . . . . . . . . . . . .

2. Peasant agriculture: the roots of the agroecological proposal .....................

2.1 The extent and significance of peasant agriculture . .3

2.2 Agroecological features of smallholder farming systems . . . . . . . . . . . . . . . 3

2.3 The productivity, efficiency and resiliency of peasant agriculture ................. 4

3. The scaling up of agroecology. . . . . . . . 6

4. Cuba. . . . . . . . . . . . . . . . . . 6

5. Brazil. . . . . . . . . . . . . . . . . . . 7

6. Philippines. . . . . . . . . . . . . . . . . . . . 9

7. Sustainable agricultural intensification in Africa. . . . . 10

8. Final reflections. . . . . . . . . . . . . . . . . . . 12

\section{Introduction}

The growing push toward industrialization and globalization with its emphasis on export crops including transgenic crops such as soybeans for cattle feed for countries such as China, Europe, USA, and the rapidly increasing demand for biofuel crops (sugar cane, maize, soybean, oil palm, eucalyptus, etc.) are increasingly reshaping the agriculture and food supply of many developing nations, with yet unknown economic, social and ecological impacts and risks (HoltGimenez and Patel 2009). Despite these unfolding trends, the peasant or small farm sector that comprises myriad of ecologically based agricultural styles, offers promising 
models for promoting biodiversity, sustaining yield without agrochemicals, and conserving ecological integrity while accounting for no less than $50 \%$ of the agricultural output for domestic consumption in most countries (ETC Group 2009).

The realization of the contribution of peasant agriculture to food security in the midst of scenarios of climate change, economic and energy crisis led to the concepts of food sovereignty and agroecologically based production systems to gain much worldwide attention in the last two decades. Two recent major international reports (IAASTD 2009; de Schutter 2010) state that in order to feed nine billion people in 2050, we urgently need to adopt the most efficient farming systems and recommend for a fundamental shift towards agroecology as a way to boost food production and improve the situation of the poorest. Both reports based on broad consultations with scientists and extensive literature reviews contend that small-scale farmers can double food production within 10 years in critical regions by using agroecological methods already available. The food challenge will be met using environmentally friendly and socially equitable technologies and methods, in a world with a shrinking arable land base (which is also being diverted to produce biofuels), with less and more expensive petroleum, increasingly limited supplies of water and nitrogen, and within a scenario of a rapidly changing climate, social unrest, and economic uncertainty (IAASTD 2009). The only agricultural system that will be able to confront future challenges is one that will exhibit high levels of diversity, productivity, and efficiency top left quadrant in Fig. 1.

Given the present and predicted near future climate, energy and economic scenarios, agroecology has emerged as one of the most robust pathways towards equitable and sustainable development available today. Agroecology is providing the scientific, methodological, and technological basis for a new "agrarian revolution" worldwide (Altieri 2009; Ferguson and Morales 2010; Wezel and Soldat 2009; Wezel et al. 2009). Agroecology-based production systems are biodiverse, resilient, energetically efficient, socially just, and comprise the basis of an energy, productive and food sovereignty strategy (Altieri 1995; Gliessman 1998). Agroecological initiatives aim at transforming industrial agriculture partly by transitioning the existing food systems away from fossil fuel-based production largely for agroexport crops and biofuels towards an alternative agricultural paradigm that encourages local/national food production by small and family farmers based on local innovation, resources, and solar energy. This implies access of peasants to land, seeds, water, credit, and local markets, partly through the creation of supportive economic policies, financial incentives, market opportunities, and agroecological technologies (Vía Campesina 2010). Agroecological systems are deeply rooted in the ecological rationale of traditional small-scale agriculture, representing long established examples of successful agricultural systems characterized by a tremendous diversity of domesticated crop and animal species maintained and enhanced by ingenuous soil, water, and biodiversity management regimes, nourished by complex traditional knowledge systems. Such systems have fed much of the region's population for centuries and continue to feed people in many parts of the planet (Koohafkan and Altieri 2010).

In this paper, we analyze the fundamental reasons why the promotion of an agroecological development paradigm based on the revitalization of small farms which emphasizes
Fig. 1 Features of green agroecosystems of the future: productivity, diversity, integration, and efficiency (Funes-Monzote 2009)

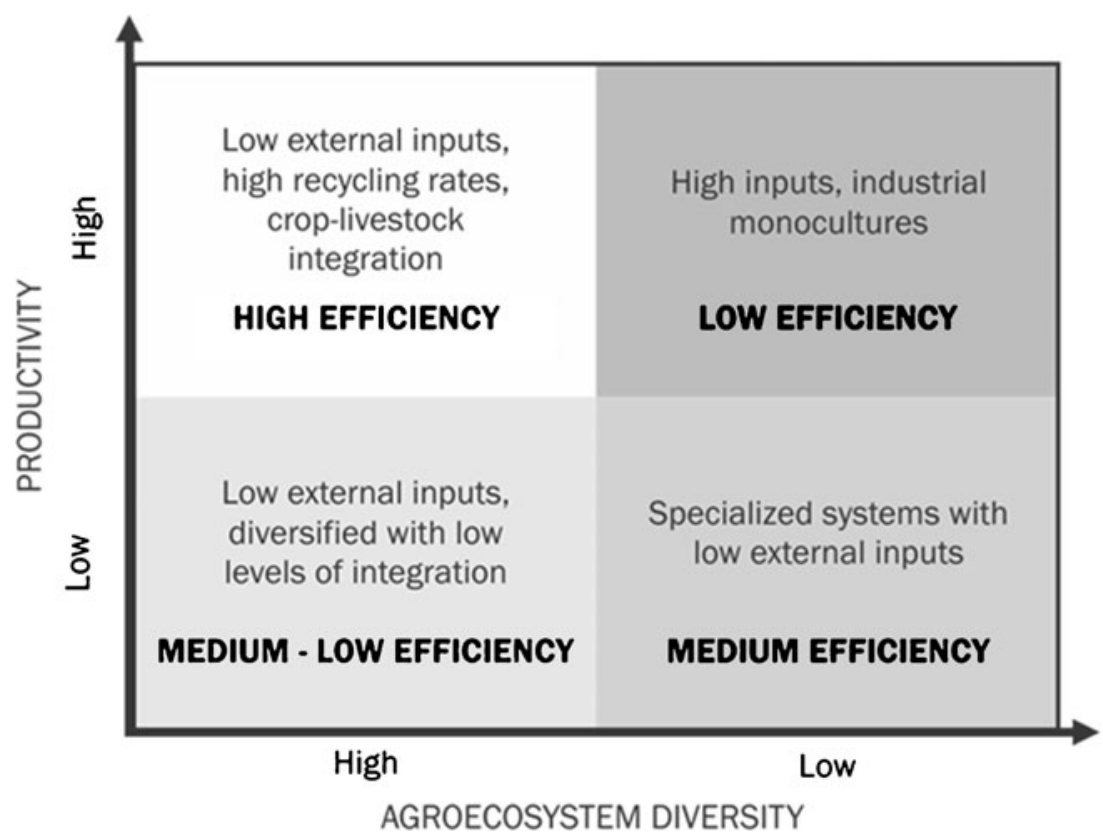


diversity, synergy, recycling and integration, and social processes that value community involvement and empowerment, is the only viable option to meet the world's food needs in this age of increasing oil prices and climate change. We also analyze the socioecological features and significance of peasant agriculture and the impacts that hundreds of agroecologically based projects in Cuba, Brazil, Philippines, and some African countries have had on the environment and food production.

\section{Peasant agriculture: the roots of the agroecological proposal}

\subsection{The extent and significance of peasant agriculture}

Most developing countries have a significant peasant population embedded in hundreds of ethnic groups with a history that can be traced back more than 10,000 years practicing traditional agriculture. In Latin America, peasant production units reach no less than 16 million small farmers contribute with approximately $41 \%$ of the agricultural output for domestic consumption, and are responsible for producing at the regional level $51 \%$ of the maize, $77 \%$ of the beans, and $61 \%$ of the potatoes. In Brazil alone, there are about 4.8 million family farmers (about $85 \%$ of the total number of farmers) that occupy $30 \%$ of the total agricultural land of the country. Such family farms control about $33 \%$ of the area sown to maize, $61 \%$ of that under beans, and $64 \%$ of that planted to cassava, thus producing $84 \%$ of the total cassava and $67 \%$ of all beans (Altieri 2004). Africa has approximately 33 million small farms, representing $80 \%$ of all farms in the region. The majority of African farmers (many of them are women) are smallholders, with two thirds of all farms below 2 ha and $90 \%$ of farms below 10 ha. Most small farmers practice "low-resource" agriculture producing the majority of grains, almost all root, tuber and plantain crops, and the majority of legumes consumed in the region. In Asia, China alone accounts for almost half the world's small farms (on 193 million ha), followed by India with $23 \%$, and Indonesia, Bangladesh, and Vietnam. Of the majority of more than 200 million rice farmers who live in Asia, few cultivate more than 2 ha of rice. China has probably 75 million rice farmers who still practice methods similar to those used more than 1,000 years ago. Local cultivars, grown mostly on upland ecosystems and/or under rain-fed conditions, make up the bulk of the rice produced by Asian small farmers.

Emerging research documents that worldwide, smallholder agroecological production contributes substantially to food security, rural livelihoods, and local and even national economies, yet these contributions have not been adequately appreciated. There are 1.5 billion rural people living on 380 million farms; 410 million practice plant gathering in forests and savannas; 190 million pastoralists and well over 100 million peasant fishers. At least 370 million of these are indigenous peoples, occupying about 92 million farms. Together, these peasants make up almost half the world's peoples and they grow in plots averaging 2 ha at least $70 \%$ of the world's food, implying that peasants feed most of the 712 million hungry people that live in rural and remote areas and no less than one third of the 238 million food insecure people that live in towns and cities (ETC Group 2009). In fact, most of the food consumed today in the world is grown from peasant-bred seeds without industrial agrochemicals. Indigenous farmers and peasants have bred 5,000 domesticated crop species and have donated more than 1.9 million plant varieties to the world's gene banks (ETC Group 2009).

\subsection{Agroecological features of smallholder farming systems}

In many areas of the developing world, traditional farmers have developed and/or inherited complex farming systems, adapted to the local conditions that have helped them to sustainably manage harsh environments and to meet their subsistence needs, without depending on mechanization, chemical fertilizers, pesticides, or other technologies of modern agricultural science (Toledo et al. 1985). The persistence of more than 3 million ha under traditional agriculture in the form of raised fields, terraces, polycultures, agroforestry systems, etc., document a successful indigenous agricultural strategy and comprises a tribute to the creativity of peasants throughout the planet (Wilken 1987).

Despite the myriad of agricultural systems, most traditional agroecosystems exhibit five similar remarkable features (Altieri 2004; Koohafkan and Altieri 2010):

1. high levels of biodiversity that play key roles in regulating ecosystem functioning and also in providing ecosystem services of local and global significance;

2. ingenious systems and technologies of landscape, land, and water resource management and conservation that can be used to improve management of agroecosystems;

3. diversified agricultural systems that contribute to local and national food and livelihood security;

4. agroecosystems that exhibit resiliency and robustness to cope with disturbance and change (human and environmental) minimizing risk in the midst of variability;

5. agroecosystems nurtured by traditional knowledge systems and farmers innovations and technologies;

6. sociocultural regulated by strong cultural values and collective forms of social organization including customary institutions for agroecological management, normative arrangements for resource access and benefit sharing, value systems, rituals, etc.

At the field level, one of the salient features of peasant farming systems is their high degree of plant diversity in the 
form of polycultures and/or agroforestry patterns (Chang 1977). This strategy of minimizing risk by planting several species and varieties of crops stabilizes yields over the long term, promotes diet diversity, and maximizes returns even with low levels of technology and limited resources. Such biodiverse farms are endowed with nutrient-enriching plants, insect predators, pollinators, nitrogen-fixing and nitrogen-decomposing bacteria, and a variety of other organisms that perform various beneficial ecological functions. Traditional agroecosystems also contain populations of variable and adapted landraces as well as wild and weedy relatives of crops. Such genetic diversity provides security to farmers against diseases, pests, droughts, and other stresses and also allows farmers to exploit the full range of agroecosystems existing in each region that display differences in soil quality, altitude, slope, water availability, etc. Genetic diversity heightens stability of the cropping systems and enables farmers to exploit different microclimates and to derive multiple nutritional and other uses from the genetic variation among the species (Clawson 1985; Perfecto et al. 2009). Rural women have traditionally carried out much of the biodiversity field conservation activities. Women are thus a key source of knowledge about on-farm seed conservation, cultivation, and local crop-based gastronomy in their respective communities.

Despite the fact that market penetration, migration, population growth, political reform, introduction of new technology, and other factors have accelerated the pace of change in rural areas, many of these traditional systems have stood the test of time documenting a successful and resilient indigenous agricultural strategy, representing models of sustainability as they promote biodiversity, thrive without agrochemicals, and sustain year-round yields in the midst of socioeconomic upheavals and environmental variability. Well into the first decade of the twenty-first century, there are in the world millions of smallholders, family farmers, and indigenous people practicing resource-conserving farming which is a testament to the remarkable resiliency of agroecosystems in the face of continuous environmental and economic change, while contributing substantially to food security at local, regional, and national levels (Toledo and Barrera-Bassols 2009). For these reasons, most agroecologists acknowledge that traditional agroecosytems have the potential to bring solutions to many uncertainties facing humanity in an era of climate change, energy and financial crisis.

The assemblage of traditional systems still existing in many countries of Latin America, Asia, and Africa comprise a globally important ingenious agricultural heritage that reflects the value of the diversity of agricultural systems adapted to different environments and tell a fascinating story of the ability and ingenuity of humans to adjust and adapt to the vagaries of a changing physical and material environment from generation to generation and leave indelible imprints of an abiding commitment to conservation and respect for their natural patrimony. These systems comprise a Neolithic legacy of considerable importance, yet modern agriculture constantly threatens the sustainability of this inheritance (Altieri and Koohafkan 2008).

\subsection{The productivity, efficiency, and resiliency of peasant agriculture}

Proponents of the Green Revolution and other modernization schemes assume progress and achieving development in traditional agroecosystems as inevitably requiring the replacement of local crop varieties for improved ones, and that the economic and technological integration of traditional farming systems into the global system is a positive step that enables increased production, income, and commonly well-being. Although the conventional wisdom is that small family farms are backward and unproductive and that peasant agriculture generally lacks the potential of producing meaningful marketable surplus, it does ensure food security. Many scientists wrongly believe that traditional systems do not produce more because hand tools and draft animals put a ceiling on productivity. Productivity may be low but the causes appear to be more social, not technical. When the subsistence farmer succeeds in providing food, there is no pressure to innovate or to enhance yields (Rosset 1999; Altieri 2002).

Despite these assertions, small family farms are much more productive than large farms if total output is considered rather than yield from a single crop. Integrated farming systems in which the small-scale farmer produces simultaneously grains, fruits, vegetables, fodder, and animal products out-produce yield per unit of single crops such as corn (monocultures) on large-scale farms. A large farm may produce more corn per hectare than a small farm in which the corn is grown as part of a polyculture that also includes beans, squash, etc. In polycultures developed by smallholders productivity in terms of harvestable products per unit area is higher than under sole cropping with the same level of management (Dorward 1999). Yield advantages can range from $20 \%$ to $60 \%$, because polycultures reduce of losses due to weeds, insects, and diseases, and make a more efficient use of the available resources of water, light, and nutrients. In Mexico, 1.73 ha plot of land has to be planted with maize monoculture to produce as much food as 1 ha planted with a mixture of maize, squash, and beans. In addition, the maize-squash-bean polyculture produces up to $4 \mathrm{t} / \mathrm{ha}$ of dry matter for plowing into the soil, compared with $2 \mathrm{t}$ in a maize monoculture (Gliessman 1998). The practice of growing 'milpa' (maize many times combined with beans) is the foundation of food security in many Latin American rural communities. A study by Isakson (2009) in Guatemala shows that although most peasants are well 
aware of the potential to increase their returns from cash crops or other alternative economic activities, $99 \%$ of the households surveyed maintained that the practice was important to their family's food security. Milpa's contribution to the peasantry's food security represents much more than the calories it generates. It also provides a near guarantee that a family's basic sustenance needs will be met. Sanders (1957) reported that in the mid-1950s, polycultures grown in traditional chinampas in Mexico exhibited maize yields of 3.5 to $6.3 \mathrm{t} / \mathrm{ha}$. In comparison, average maize yields in the USA in 1955 were $2.6 \mathrm{t} / \mathrm{ha}$, and did not pass the $4 \mathrm{t} / \mathrm{ha}$ mark until 1965. Each hectare of chinampa could produce enough food for 15 to 20 persons per year at modern subsistence levels.

Increasing evidence shows that most peasant systems are productive despite their low use of chemical inputs. In the Amazon, the Kayapo yields are roughly 200\% higher than colonist systems and 175 times that of livestock. Generally, agricultural labor has a high return per unit of input. The energy return to labor expended in a typical highland Mayan maize farm is high enough to ensure continuation of the present system. To work a hectare of land, which normally yields $4.2 \mathrm{G}$ calories, requires some $395 \mathrm{~h}$; thus, an hour's labor produces about $10.7 \mathrm{M}$ calories. A family of three adults and seven children eat about $4.8 \mathrm{G}$ calories of maize per year, thus current systems provide food security for a typical family of five or seven people. Also in these systems, favorable rates of return between inputs and outputs in energy terms are realized. On Mexican hillsides, maize yields in hand-labor dependent systems are about $1,940 \mathrm{~kg} / \mathrm{ha}$, exhibiting an output/input ratio of $11: 1$. In Guatemala, similar systems yield about $1,066 \mathrm{~kg} / \mathrm{ha}$ of maize, with an energy efficiency ratio of 4.84 . Yield per seed planted vary from 130 to 200 . When animal traction is utilized, yields do not necessarily increase but the energy efficiency drops to values ranging from 3.11 to 4.34 . When fertilizers and other agrochemicals are utilized yields can increase to levels of 5-7 t/ha, but energy ratios are highly inefficient (less than 2.5). In addition, most peasants are poor and generally cannot afford such inputs unless agrochemicals are subsidized (Pimentel and Pimentel 1979). In Cuba, small farmers using agroecological methods obtain yields per hectare sufficient to feed about 15-20 people per year with energy efficiencies of no less than 10:1 (Table 1).

Recent research shows that many small farmers cope with and even prepare for climate change, minimizing crop failure through increased use of drought tolerant local varieties, water harvesting, mixed cropping, agroforestry, soil conservation practices, and a series of other traditional techniques (Altieri and Koohafkan 2008). Observations of agricultural performance after extreme climatic events in the last two decades have revealed that resiliency to climate disasters is closely linked to the level of on-farm biodiversity typical of small farms. A survey conducted in Central
Table 1 Two Cuban small-scale farming systems models exhibiting high productivity, high energy efficiency, and high diversity (FunesMonzote et al. 2011)

\begin{tabular}{lll}
\hline Farm & $\begin{array}{l}\text { Cayo Piedra, } \\
\text { Matanzas }\end{array}$ & $\begin{array}{l}\text { Del Medio, } \\
\text { Sancti Spíritus }\end{array}$ \\
\hline Area (ha) & 40 & 10 \\
Energy (GJ/ha/year) & 90 & 50.6 \\
Protein (kg/ha/year) & 318 & 434 \\
People fed/ha/year (energy) & 21 & 11 \\
People fed/ha/year (protein) & 12.5 & 17 \\
Energy efficiency (output/input) & 11.2 & 30 \\
Land Equivalent Ratio & 1.67 & 1.37 \\
\hline
\end{tabular}

Cayo Piedra farm typically includes between 10 and 15 different species in crop rotations (maize, beans, sugar beets, cabbage, potatoes, sweet potatoes, taro, carrot, cassava, squash, and pepper) and permanent crops such as banana and coconut. Del Medio farm is a highly diversified farm with more than 100 species of crops, animals, trees, and other wild species that are being managed using permacultural practices

American hillsides after Hurricane Mitch showed that farmers using diversification practices such as cover crops, intercropping and agroforestry suffered less damage than their conventional monoculture neighbors. The survey, spearheaded by the Campesino a Campesino movement, mobilized 100 farmer-technician teams to carry out paired observations of specific agroecological indicators on 1,804 neighboring sustainable and conventional farms. The study spanned 360 communities and 24 departments in Nicaragua, Honduras, and Guatemala. It was found that sustainable plots had $20-40 \%$ more topsoil, greater soil moisture and less erosion and experienced lower economic losses than their conventional neighbors (Holt-Gimenez 2006). Similarly in Sotonusco, Chiapas, coffee systems exhibiting high levels of vegetational complexity and plant diversity suffered less damage from Hurricane Stan than more simplified coffee systems (Philpott et al. 2009). Forty days after Hurricane Ike hit Cuba in 2008 researchers conducted a farm survey in the Provinces of Holguin and Las Tunas and found that diversified farms exhibited losses of $50 \%$ compared to $90 \%$ or $100 \%$ in neighboring monocultures. Likewise, agroecologically managed farms showed a faster productive recovery (80-90\% 40 days after the hurricane) than monoculture farms (Machin-Sosa et al. 2010). Agroecological innovations disseminated by the National Program for Local Innovation in Cuba have demonstrated to increase food security and food sovereignty while adapting to- and mitigating of climate change (Ríos et al. 2011). All these studies emphasize the importance of enhancing plant diversity and complexity in farming systems to reduce vulnerability to extreme climatic events. The fact that many peasants commonly manage polycultures and/or agroforestry systems points at the need to re-evaluate indigenous technology as 
a key source of information on adaptive capacity centered on the selective, experimental, and resilient capabilities of farmers in dealing with climatic change. Understanding the agroecological features of traditional agroecosystems can serve as the foundation for the design of climate change resilient agricultural systems (Altieri and Koohafkan 2008).

\section{The scaling up of agroecology}

The analysis of dozens of farmer-led and NGO-led agroecological projects show convincingly that agroecological systems are not limited to producing low outputs, as some critics have asserted. Increases in production of $50-100 \%$ are fairly common with most alternative production methods. In some of these systems, yields for crops that the poor rely on most-rice, beans, maize, cassava, potatoes, and barley - have been increased by several-fold, relying on labor and know-how more than on expensive purchased inputs, and capitalizing on processes of intensification and synergy (Uphoff 2002). In a study of 208 agroecologically based projects and/or initiatives throughout the developing world, Pretty et al. (2003) documented clear increases in food production over some 29 million ha, with nearly nine million households benefiting from increased food diversity and security. Promoted sustainable agriculture practices led to $50-100 \%$ increases in per hectare food production (about $1.7 \mathrm{Mg} /$ year/household) in rain-fed areas typical of small farmers living in marginal environments; that is an area of about 3.58 million ha, cultivated by some 4.42 million farmers. Such yield enhancements are a true breakthrough for achieving food security among farmers isolated from mainstream agricultural institutions.

What started as localized efforts in several isolated rural areas promoted by NGO personnel and community leaders has now expanded to hundreds of peasant communities throughout many countries. Success in scaling up has not only depended on the use of a variety of agroecological improvements that in addition to farm diversification favoring a better use of local resources, but also on human capital enhancement and community empowerment through training and participatory methods as well as higher access to local-regional markets, government support such as credit, seeds, and agroecological technologies. In Latin America, a key factor in agroecological expansion was the Campesino a Campesino (CAC) movement which a "peasant pedagogic method" promoting a horizontal process of exchange of ideas and innovations among farmers. It was via the CAC method that soil conservation practices were introduced in Honduras, and hillside farmers adopting the various techniques tripled or quadrupled their yields from $400 \mathrm{~kg} / \mathrm{ha}$ to $1,200-1,600 \mathrm{~kg}$. This tripling in per-hectare grain production has ensured that the 1,200 families that participated in the program have ample grain supplies for the ensuing year. The adoption of velvet bean (Mucuna pruriens) which can fix up to $150 \mathrm{~kg}$ of nitrogen per ha as well as produce $35 \mathrm{t}$ of organic matter per year, helped tripled maize yields to $2,500 \mathrm{~kg} / \mathrm{ha}$. Labor requirements for weeding were cut by $75 \%$ and herbicides eliminated entirely Later organized social rural movements such as the Vía Campesina, the Landless Workers Movement (MST) in Brazil, Asociación Nacional de Agricultores Pequeños (ANAP) of Cuba, and others massively adopted agroecology as a banner underlying their food production approach to food sovereignty. As a science, agroecology is compatible with the struggle and vision of rural movements because it does not question peasant rationale but rather builds upon it, it does not attempt to radically modify local farming systems, instead optimizes their design and uses local resources and skills. Also agroecology is socially activating as it requires community participation and horizontal methods of knowledge exchange to work (Altieri and Toledo 2011).

\section{Cuba}

During the last two decades, Cuba has experimented a unique process of social, technological, energetic and food system transformation as a response to the crisis prompted by the collapse of the Soviet Union. Since the beginning of the revolution and especially since the special period at the beginning of 1990s, the Cuban people have been involved in heroic attempts to reach food sovereignty in the midst of an inhumane US trade embargo, and after the collapse of imports of petroleum, agrochemicals and machinery from the Soviet bloc. Top agricultural Cuban researchers (Funes et al. 2002) reported in the book Sustainable Agriculture and Resistance: Transforming Food Production in Cuba how the island was unable to import either food or materials needed for conventional agriculture and thus turned inward to selfreliance. Sustainable agriculture, organic farming, urban gardens, smaller farms, animal traction, and biological pest control all became part of the new Cuban agriculture.

The growth of the agroecological movement can be partly linked to the training, extension, and research activities of the Asociación Cubana de Técnicos Agrícolas y Forestales (ACTAF) in its goals to promote agroecology throughout the island. But what has constituted a true agroecological revolution have been the efforts of about 100,000 families - almost half the population of independent small farmers in Cubawho are members of ANAP (National Association of Small Farmers), practice agroecological diversification methods in their farms producing much more food per hectare than any commercial, industrial agriculture farm. These family farmers, many of whom are part of the Campesino a Campesino (Farmer-to-Farmer) movement, produce over $65 \%$ of the 
country's food, on only $25 \%$ of the land (Rosset et al. 2011). The recent study of Machin-Sosa et al. (2010) revealed that in less than a decade, the active participation of small farmers in the process of technological innovation and dissemination through Farmer-to-Farmer models that focus on sharing experiences, strengthening local research and problem-solving capacities has produced a major impact. It is estimated that depending on the region, agroecological practices are used in $46-72 \%$ of the peasant farms producing over $70 \%$ of the domestic food production, e.g., $67 \%$ of roots and tubers, $94 \%$ of small livestock, $73 \%$ of rice, $80 \%$ of fruits and most of the honey, beans, cocoa, maize, tobacco, milk, and meat production (Varela Pérez 2011).

Another study conducted by Funes-Monzote et al. (2009) shown that small farmers using integrated crop-livestock farming systems were able to achieve a three-fold increase in milk production per unit of forage area (3.6 t/ha/year) as well as a seven-fold increase in energy efficiency (Fig. 2). Energy output (21.3 GJ/ha/year) was tripled and protein output doubled (141.5 kg/ha/year) via diversification strategies of specialized livestock farms.

Given the economic, energy and climatic conditions of the island, the Cuban peasantry supported by agroecological strategies exhibits today the highest indexes of productivity, sustainability, and resiliency. Agroecology, as being promoted by Campesino a Campesino movement is demonstrating to be the most efficient, cheap, and stable way of producing food per unit of land, input, and labor. As this process advances, more small farmers join this agroecological revolution (the government now is giving up to 13.5 ha to families interested in becoming farmers): so far, there are 110,000 new farmers cultivating in usufruct more than 1 million ha of land left abandoned by the monoculture-industrial system prevailing in the island before 1990. The goal is to reach 1.5 million ha under agroecological management, enough to make the island food sovereign. Cuba's achievements in urban agriculture

A

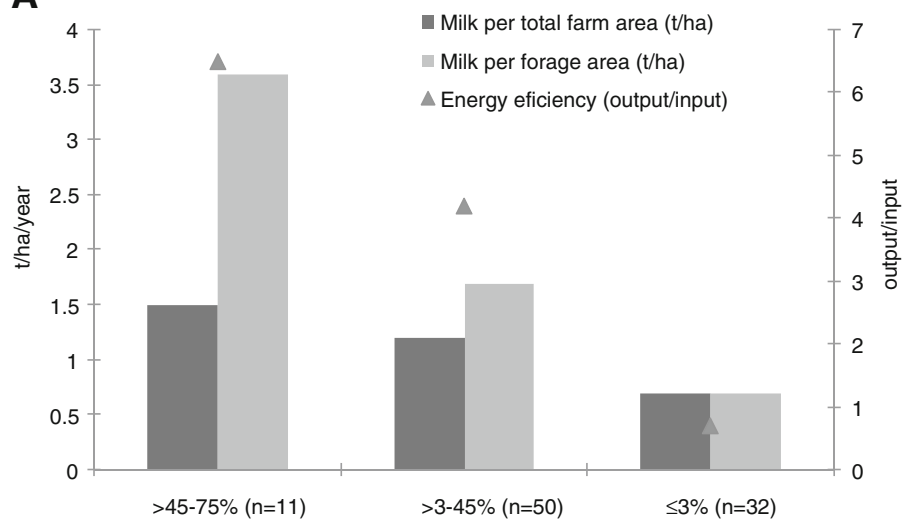

Fig. 2 a Productivity and energy efficiency of dairy systems in three crop-livestock integration percentages (high, between or $=45-75$ of area under crops; medium, between 3 and 45 and low, $\leq 3)$. $N=93$ farms have also grown and are truly remarkable: 383,000 urban farmers farm more than 50,000 ha of otherwise unused land and producing around 4 million tons of vegetables (top urban farms reach a yearly yield of $20 \mathrm{~kg} / \mathrm{m}^{2}$ of edible plant material using no synthetic chemicals) enough to supply $40-60 \%$ or more of all the fresh vegetables in cities such as Havana, Villa Clara, and others (Koont 2009). No other country in the world has achieved this level of success with an extremely low dependence on fossil fuels.

\section{Brazil}

The industrial agricultural model imposed by Brazil's agrarian elites is the main factor behind the concentration of land ownership, rural violence, the rural exodus to cities, and consequent urban unemployment. It is also associated with an unprecedented level of degradation of biodiversity, soils, and water resources. In addition to having been instrumental in the destruction of the cultures of traditional peoples, this development model generates the dependency and food insecurity of thousands of rural and urban families in Brazil.

Since the 1970s, the social responses to this scenario have led to the emergence of a plethora of innovative projects in rural communities across Brazil. Despite the enormous diversity of actors and socioenvironmental contexts involved, these experiences have gradually become identified with the guiding principles of an alternative project for the rural world. These initiatives on agroecology have been championed by the National Agroecology Alliance (ANA) - "Articulação Nacional de Agroecologia." ANA is not an institutionalized movement since it has no formal structure. Its role is to connect civil society networks and rural social movements that are mobilized through autonomous social dynamics organized from local to the national level. It also includes the Brazilian Agroecology Association (ABA-Agroecologia), a

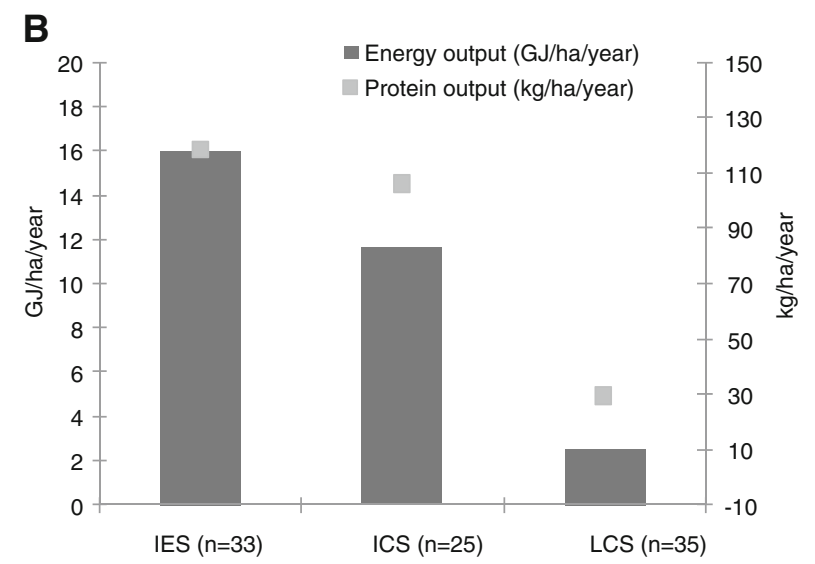

throughout the country. b Energy output and protein output in Integrated Experimental Systems (IES), Integrated Commercial Systems (ICS), and Livestock Commercial Systems 
network acting as a focal point for the growing number of educators, researchers, and extensionists whose professional work is guided by the agroecological paradigm.

One of the strengths of the Brazilian agroecological movement has been the documentation and dissemination of the results of successful decentralized agroecological innovations which have contributed positively to the livelihoods of local populations on a sustainable basis. To this end, ANA and ABA-Agroecologia are presently coordinating an initiative designed to identify, record, and make available information on successful experiences via the internet through the Agroecologia em Rede system (see www. agroecologiaemrede.org.br).

One of these experiences is the work of the NGO AS-PTA in Southern Brazil (the north of Santa Catarina State), with family farmers producers of conventional maize, in the search for techno-economic alternatives. A comparative analysis of conventional maize production systems and agroecological transition systems was carried out during the 2008-2009 agricultural cycle which coincided with a year of climatic extremes (Almeida et al. 2009). Due to the severity of the drought that occurred during the cycle, a phenomenon that is becoming ever more frequent in Southern Brazil, the conventional maize producers exhibited an average yield loss of $50 \%$, reaching productivity levels of 4,500 $\mathrm{k} / \mathrm{ha}$. However, the producers who had switched to incorporating agroecological practices in their production systems (use of local seeds + green manures + rock dust + minimum tillage), experienced smaller losses - around 20\% - confirming the greater resilience of these systems compared to those using agrochemicals. Their average productivity levels reached $4,200 \mathrm{~kg}$ /ha but their average production costs were significantly lower, revealing the capacity of transitional systems to generate a positive economic surplus despite facing adverse climatic conditions.

This data corroborates previous assessments of the impact of agroecological innovations on traditional grain production systems conducted in the same region 10 years earlier (Petersen et al. 1999). At the time, it was found that the same innovations in farm management now being employed by conventional producers were capable of generating in a short time increases in maize crop productivity of around $60 \%$ without the need of large financial investment. This experience shows that the restoration of ecological processes in the soil-plant system through the use of locally adapted genotypes, combined with soil fertility management practices based on biomass incorporation, has positive effects on annual crop production systems even over a short time period. This fact contradicts the widely accepted idea that agroecological transition processes necessarily involve an initial drop in economic profits. In the current context of climatic uncertainty and the strong squeeze on farming caused by increases in production costs linked to falling commodity prices, positive economic results have been obtained even in the first year in which ecological processes have been restored, drastically reducing dependency on agrochemicals, increasing the system's capacity to adapt to climatic extremes, and maintaining acceptable productivity levels.

Based on the data collected in the study, an estimate was made on the positive impacts of a hypothetical public program supporting agroecological transition in the region. Taking into account a total population of 48,000 farming families, the potential for increases in the regional production of basic grains (maize+beans) was around 170,000 t with average increases of US $\$ 563.00$ on the annual income of family farms. Although these represent rough estimates, they highlight the technical and economical potential of scaling up low-cost agroecological technologies, thus responding to the financial crisis facing family farming in Southern Brazil, which emerged in the 1990s with the liberalization of agricultural markets. Unfortunately, the Brazilian state has opted to allocate ever more funds to programs aimed at modernizing family farming on the basis of the scientific-technological precepts of the Green Revolution. To this end, it created and systematically extended the National Family Farming Support Program (PRONAF), a public program that provides easy credit for purchasing agrochemicals and motorized equipment.

One of these government programs which promoted conservation tillage was not successful reaching small farmers due mainly to the high costs of machinery and inputs. Herbicide use comprises $25 \%$ of the costs of production, a prohibitive technology given income levels in the region. Instead, many hillside family farmers practicing annual cropping, using inventive self-reliance modified the conventional no-till system by initially leaving plant residues on the soil surface and first noticing reductions in soil erosion and lower fluctuations in soil moisture and temperature, and later that repeated applications of fresh biomass improved soil quality and crop performance. Several researchers and extension agents from the state government and universities joined forces with farmers experimenting for more than two decades on green manure/cover crops and their incorporation into conservation tillage systems. Both farmers and researchers report that using cover crops minimize soil erosion and weed growth and exhibit positive effects on soil physical, chemical, and biological properties. These novel systems do not depend on herbicides for weed control but rely instead on the use of crop mixtures for both summer and winter cover cropping which leave a thick residue mulch layer on which after the cover crops are rolled, traditional grain crops (corn, beans, wheat, onions, tomatoes, etc.) are directly sowed or planted, suffering very little weed interference during the growing season and reaching agronomically acceptable yield levels. When cover crop combinations of vetch, fodder radish, and rye are used, the residues have a notorious weed suppressive. Farmers have reported that the emergence of certain weeds declines 
monotonically as mulch rate (residue amount and thickness) increases. Some weed species in the litter layer develop shallow root systems in the litter layer-soil interface which makes them easier to control. Research conducted in these systems shows, as revealed in Fig. 3, that many factors and interactions emerging from the management of these organic no-till systems by farmers affect weed dynamics and hence crop productivity (Altieri et al. 2011).

\section{Philippines}

A recent report of what probably can be considered the largest study undertaken on sustainable agriculture in Asia focuses on the benefits of organic production in rice-based small-scale farming systems. The study which analyzes the work of MASIPAG, a network of small-scale farmers, farmers' organizations, scientists, and non-governmental organizations (NGOs), includes data from hundreds of organic, partially organic, and non-organic farmers from across the country. The study compares findings from 280 full organic farmers,
280 in conversion to organic agriculture, and 280 conventional farmers to act as a reference group. The analysis focuses on food security, income and livelihood, yields and productivity, environmental outcomes, and farmer knowledge and empowerment. The results turn out to be very positive for the farmer-led sustainable agriculture approaches promoted by MASIPAG across the range of variables used in the comparison (Bachmann et al. 2009).

Researchers found that food security is significantly higher for organic farmers. Full organic farmers eat a more diverse, nutritious, and secure diet. Reported health outcomes are also substantially better for the organic group. The study reveals that the full organic farmers have considerably higher on-farm diversity, growing on average $50 \%$ more crops than conventional farmers, better soil fertility, less soil erosion, increased tolerance of crops to pests and diseases, and better farm management skills. The group also has, on average, higher net incomes that have increased since 2000 in contrast to stagnant or declining incomes for the reference group of conventional farmers. Per hectare net incomes of the full organic farmers are one and a half times

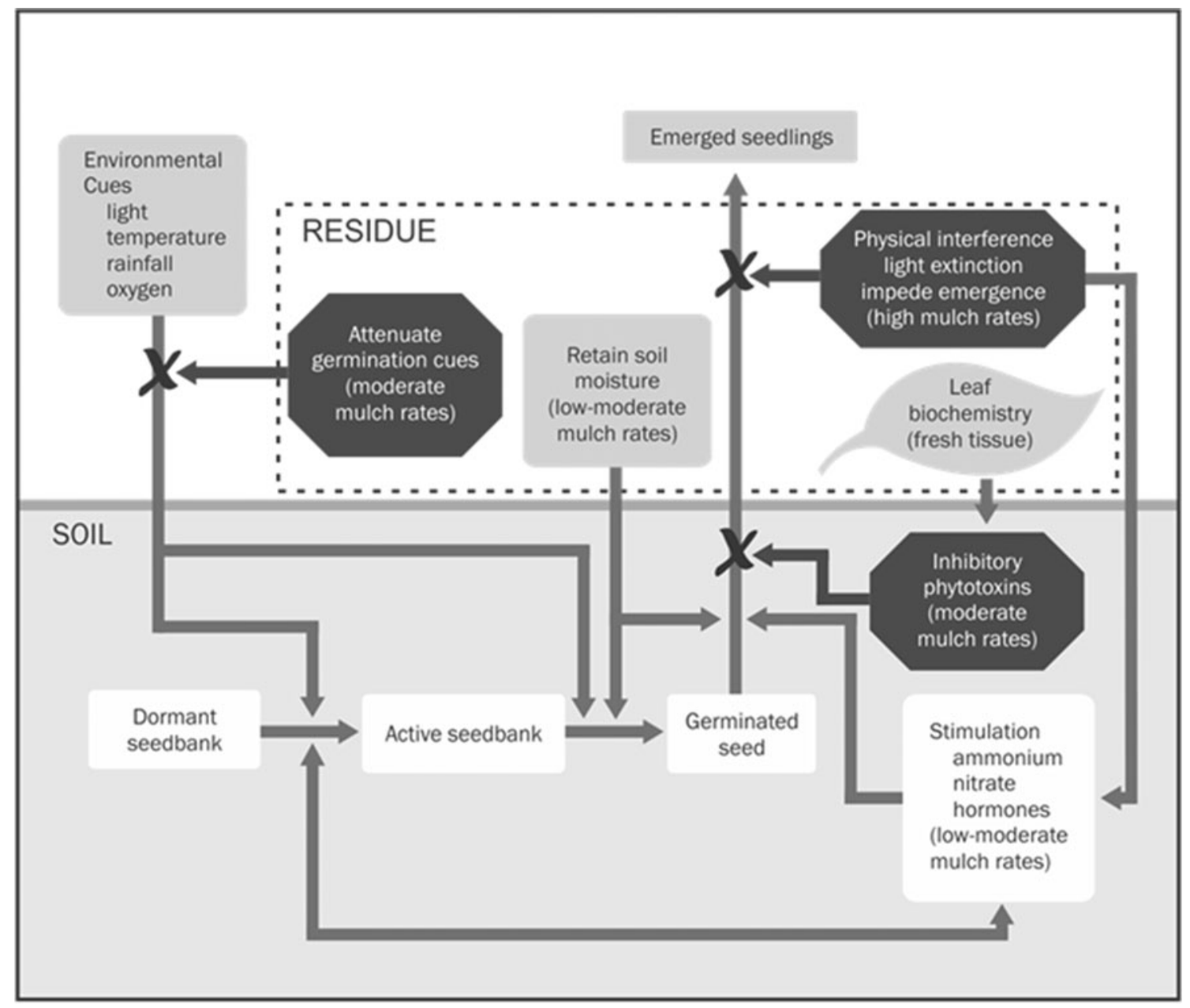

Fig. 3 The multiple effects of cover crop mulches on weed suppression (after Altieri et al. 2011) 
Table 2 Main findings of the MASIPAG study (Bachmann et al. 2009)

Farmers practicing farmer-led sustainable agriculture are:

More food secure

Eating an increasingly diverse diet

Producing a more diverse range of crops

Experiencing better health outcomes
$88 \%$ of organic farmers find their food security better or much better than in 2000 compared to only $44 \%$ of conventional farmers. Of conventional farmers, $18 \%$ are worse off. Only $2 \%$ of full organic farmers are worse off.

Organic farmers eat $68 \%$ more vegetables, $56 \%$ more fruit, $55 \%$ more protein rich staples and $40 \%$ more meat than in 2000. This is an increase between 2 and 3.7 times higher than for conventional farmers.

Organic farmers on average grow 50\% more crop types than conventional farmers.

In the full organic group $85 \%$ rate their health today better or much better than in 2000 . In the reference group, only $32 \%$ rate it positively, while $56 \%$ see no change and $13 \%$ report worse health. higher than those of conventional farmers. On average, they have a positive annual cash balance for households compared to conventional farmers who experience a deficit in the household cash balance. This means that organic farmers are less indebted than their conventional counterparts.

The findings of the study summarized in Table 2 show good outcomes particularly for the poorest in rural areas. The livelihoods (defined as net income plus subsistence) of the poorest quarter of organic farmers is one and a half times higher than the income of the poorest conventional farmers. Net income plus subsistence value of crops calculated on a per hectare basis also shows a clear, highly statistically significant advantage for the organic farmers revealing higher productivity in the organic farms.

\section{Sustainable agricultural intensification in Africa}

The UK Government's Foresight Global Food and Farming project conducted an analysis of 40 projects and programs in 20 African countries where sustainable crop intensification was promoted during the 1990 s to 2000 s. The cases included crop improvements, agroforestry and soil conservation, conservation agriculture, integrated pest management, horticulture, livestock and fodder crops, aquaculture, and novel policies and partnerships. By early 2010, these projects had documented benefits for 10.39 million farmers and their families and improvements on approximately 12.75 million ha. Food outputs by sustainable intensification via the use of new and improved varieties were significant as crop yields rose on average by 2.13 -fold (Pretty et al. 2011).

Although some of the reported yield gains reported in Table 3 depended on farmers having access to improved seeds, fertilizers, and other inputs (which more than often is not the case) in most cases food outputs were improved by additive means - by which diversification of farms resulted in the emergence of a range of new crops, livestock, or fish that added to the existing staples or vegetables already being cultivated. These new system enterprises or components included: aquaculture for fish raising; small patches of land used for raised beds and vegetable cultivation; rehabilitation of formerly degraded land; fodder grasses and shrubs that provide food for livestock (and increase milk productivity); raising of chickens and zero-grazed sheep and goats; new crops or trees brought into rotations with maize or sorghum, adoption of short-maturing varieties (e.g., sweet potato and cassava) that permit the cultivation of two crops per year instead of one.

One of the most successful diversification strategies has been the promotion of tree-based agriculture. Agroforestry

Table 3 Summary of productivity outcomes from African case studies (Pretty et al. 2011)

Thematic focus

Crop variety and system improvements

Agroforestry and soil conservation

Conservation agriculture

Integrated pest management

Horticulture and very small-scale agriculture

Livestock and fodder crops

Novel regional and national partnerships and policies

Aquaculture

Total
Area improved (ha) Mean yield increase (ratio) Net multiplicative annual increase in food production (thousand tones year ${ }^{-1}$ )

$\begin{array}{rll}391,060 & 2.18 & 292 \\ 3,385,000 & 1.96 & 747 \\ 26,057 & 2.20 & 11 \\ 3,327,000 & 2.24 & 1,418 \\ 510 & \text { nd } & \text { nd } \\ 303,025 & \text { nd } & \text { nd } \\ 5,319,840 & 2.05 & 3,318 \\ 523 & \text { nd } & \text { nd } \\ 12,753,000 & 2.13 & 5,786\end{array}$


in Malawi, Tanzania, Mozambique, Zambia, and Cameroon of maize associated with fast-growing and N-fixing shrubs (e.g., Calliandra and Tephrosia) result in an improvement in total maize production, with total maize production of $8 \mathrm{t} / \mathrm{ha}$ compared with $5 \mathrm{t}$ obtained under monoculture. In Malawi, maize yields were increased up to $280 \%$ in the zone under the tree canopy compared with the zone outside the tree canopy (World Agroforestry Center 2009). In Zambia, recent unpublished results of 15 sets of observations conducted by the CFU in the 2008 growing season found that unfertilized maize yields in the vicinity of Faidherbia trees averaged $4.1 \mathrm{t} / \mathrm{ha}$, compared to $1.3 \mathrm{t}$ nearby but beyond the tree canopy. The trees provide a natural form of fertilizer free of charge through leaf fall at the beginning of the rains as the crops are planted. All the trees require to thrive is sunshine during the dry season, and sufficient moisture, which they obtain from their very deep root systems during the dry season after the crops are harvested. In the Maradi and Zinder Regions of Niger, there are now about 4.8 million ha of Faidherbia-dominated agroecosystems with fields harboring up to 150 trees per hectare. The Niger farmers claim that the trees improve their crop yields, and protect their crops from dry winds and their land from wind and water erosion. They also relate that the foliage and pods provide much-needed fodder for their cattle and goats during the long Sahelian dry seasons. Encouraged by the experience in Niger, several new programs to promote farmermanaged natural regeneration of Faidherbia and other species have been established in other countries across the Sahel. It is estimated that about 500,000 farmers in Malawi and the southern highlands of Tanzania maintain Faidherbia trees in their maize fields (Reij and Smaling 2008).

In Madagascar, the most important Conservation Agriculture (CA) systems adopted by farmers in relatively good fertility soils are the association of maize with legumes followed in the next season by rice. Guided by the Groupement Semis Direct de Madagascar, farmers are using the on the poorest soils the association of food crops (groundnut, Bambara bean, etc.) with Stylosanthes guianensis cv. CIAT 184 in rotation the following season with rice. One of the major drivers of CA is the occurrence of Striga asiatica in some part of the country and this was an entry point for CA extension. Also, among the reasons for CA adoption are the possibilities for farmers to grow upland rice in the hillside (known as tanety) after regeneration of the soil with a good biomass, and to associate fodder crops (Brachiaria sp.) with staple food crops such as cassava. Yield and profitability of CA plots are increasing with the number of years under CA, but saving in labor is not always consistently observed because of increasing labor due to weeding when cover crops are not correctly managed (Rakotondramanana 2011).

Farmers of Rhotia village, Karatu-Tanzania realized that crop yield increased with time under CA. In 2009 season, which suffered from drought, people harvested $20,000 \mathrm{~kg}$ maize from the $12 \mathrm{ac}(4.2 \mathrm{t} / \mathrm{ha}) ; 1,800 \mathrm{~kg}$ pigeon pea $(375 \mathrm{~kg} / \mathrm{ha})$, and $840 \mathrm{~kg}$ lablab $(175 \mathrm{~kg} / \mathrm{ha})$. CA was effective in the fight against hunger and poverty (lablab or pigeon pea sell at $1,100 \mathrm{Tsh} / \mathrm{kg}$ ). The yields under CA are generally higher and farmers noted that intercropping of maize with cover crops (pigeon pea and D. lablab) provided three harvests per season instead of two. They also learnt that the increase in crop production was brought about by improved soil conservation and water management under CA. Yields under CA increased from $1.25 \mathrm{t} / \mathrm{ha}(2004)$ to $7.0 \mathrm{t} / \mathrm{ha}$ (2009). The farmers also experienced a reduction in labor and time requirements in farm operations after one season of CA. This was brought about by reducing the number of operations during land preparation (using rippers), planting (using direct planters), weeding (using cover crop+roughing), etc. At the end of the first phase of an FAO-sponsored CA project, there were 765 farmers practicing $\mathrm{CA}$ in the northern

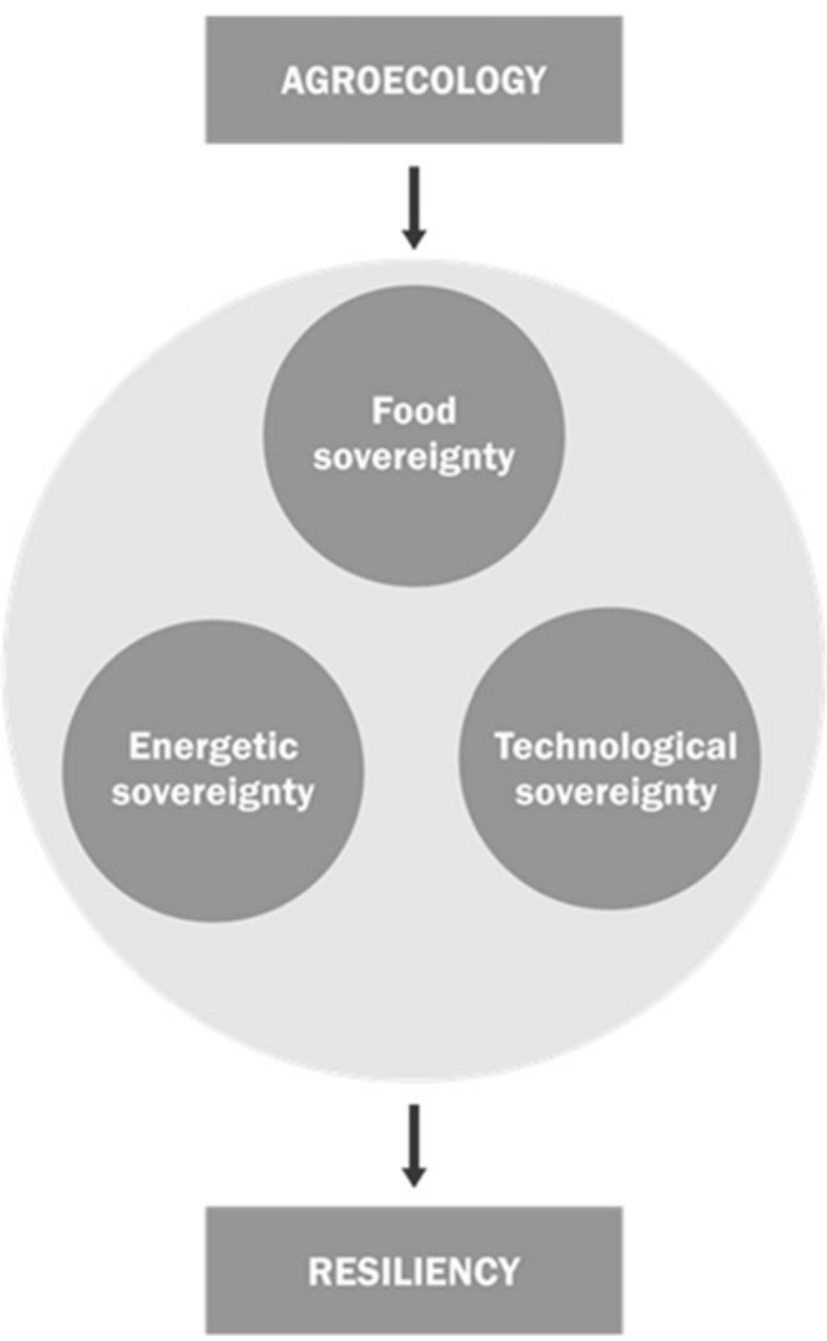

Fig. 4 The three types of sovereignty to be reached by an agricultural community or region by following agroecological principles and in the context of a resiliency strategy 
zone. More farmers adopted it during the second phase of the project reaching 3,600 farmers (Owenya et al. 2011).

\section{Final reflections}

Undoubtedly, the myriad of traditional systems still existing throughout the developing world comprise a globally important ingenious agricultural heritage that reflects the value of the diversity of agricultural systems adapted to different environments and tells a fascinating story of the ability and ingenuity of humans to adjust and adapt to the vagaries of a changing physical and material environment from generation to generation. These systems comprise a Neolithic legacy of considerable importance, yet modernization constantly threatens the sustainability of this inheritance. It is critical to preserve and rescue the ecological and cultural foundations of these systems, including the wealth and breadth of accumulated knowledge and experience in the management and use of agrobiodiversity and soil-water resources (Koohafkan and Altieri 2010).

Agricultural systems - even the most traditional onesare not static systems and in fact they are constantly changing over time. The major forces that shape current agricultural changes are: population increase and dynamics, global market forces, advances in science and technology, climatic change and variability, consumer demands, agricultural subsidies, and pressures from social movements demanding food sovereignty, land reform, and poverty reduction. Agroecologists recognize this and have used agroecological principles and practices to re-design and optimize small farming systems so that they can respond adequately to these forces and therefore have the possibility of being sustainable in a rapidly changing world. Many of the agroecologically based systems that have succeeded in terms of productivity and resiliency share most of what can be described as the pillars of sustainable management of agricultural systems:

- Increase total farm productivity in perpetuity.

- Permanent risk reduction and enhanced resiliency.

- Promotion of economic viability, social equity, and cultural diversity.

- Conservation of natural resources, enhancement of biodiversity and ecosystem services.

- Optimization of natural cycles and reducing dependency on non-renewable resources.

- Prevention of land degradation and the general environment. Obviously, a major emphasis of agroecological systems is to promote food sovereignty defined as the right of everyone to have access to safe, nutritious, and culturally appropriate food in sufficient quantity and quality to sustain a healthy life with full human dignity. However, given the expected increase in the cost of fuel and inputs, the agroecological strategy also aims at enhancing energy and technological sovereignty (Fig. 4). Energy sovereignty is the right for all people to have access to sufficient energy within ecological limits from appropriate sustainable sources for a dignified life. Technological sovereignty refers to the capacity to achieve the two other forms of sovereignty by nurturing the environmental services derived from optimizing agrobiodiversity designs that encourage synergies and efficient use of locally available resources.

Despite the positive gains that agroecological movements have had over time, still there are many factors that have limited or constrained the diffusion and implementation of agroecological initiatives more fully. Major reforms must be made in policies, institutions, and research and development agendas to make sure that agroecological alternatives are massively adopted, made equitably and broadly accessible, and multiplied so that their full benefit for sustainable food security can be realized. It must be recognized that a major constraint to the spread of agroecology has been that powerful economic and institutional interests have backed research and development for the conventional agroindustrial approach, while research and development for agroecology and sustainable approaches has in most countries been largely ignored or even ostracized (Altieri 2009).

Whether the potential and spread of local agroecological innovations described above, is scaled up to reach all the small farmers of a region depends on the ability of the various actors and organizations involved in the agroecological revolution to make the necessary alliances so that farmers can gain increasing access to agroecological knowledge as well as to land, seeds, government services, solidarity markets, and so on. Rural social movements understand that dismantling the industrial agrifood complex and restoring local food systems must be accompanied by the construction of agroecological alternatives that suit the needs of small-scale producers and the low-income nonfarming population and oppose corporate control over production and consumption. Of key importance will be the direct involvement of farmers and scientists in the formulation of the research agenda and their active participation in the process of technological innovation and dissemination through Campesino a Campesino models where researchers and extension workers can play a major facilitating role (Altieri and Toledo 2011).

Open Access This article is distributed under the terms of the Creative Commons Attribution Noncommercial License which permits any noncommercial use, distribution, and reproduction in any medium, provided the original author(s) and source are credited.

\section{References}

Almeida E, Petersen P, Pereira FJ (2009) Lidando com extremos climáticos; análise comparativa entre lavouras convencionais e em transição agroecológica no Planalto Norte de Santa 
Catarina. Agriculturas: experiências em agroecologia. Rio de Janeiro AS-PTA 6(1):28-32

Altieri MA (1995) Agroecology: the science of sustainable agriculture. Westview Press, Boulder

Altieri MA (2002) Agroecology: the science of natural resource management for poor farmers in marginal environments. Agric Ecosyst Environ 93:1-24

Altieri MA (2004) Linking ecologists and traditional farmers in the search for sustainable agriculture. Front Ecol Environ 2:35-42

Altieri MA (2009) Agroecology, small farms and food sovereignity. Mon Rev 61:102-111

Altieri MA, Koohafkan P (2008) Enduring farms: climate change, smallholders and traditional farming communities. Environment and development series 6. Malaysia: third world network

Altieri MA, Toledo VM (2011) The agroecological revolution in Latin America. J Peasant Stud 38:587-612

Altieri MA, Lana MA, Bittencourt H, Kieling AS, Comin JJ, Lovato PE (2011) Enhancing crop productivity via weed suppression in organic no-till cropping systems in Santa Catarina, Brasil. J Sustain Agric 35:1-15

Bachmann L, Cruzada E, Wright S (2009) Food security and farmer empowerment: a study of the impacts of farmer-led sustainable agriculture in the Philippines. Masipag-Misereor, Los Baños

Chang JH (1977) Tropical agriculture: crop diversity and crop yields. Econ Geogr 53:241-254

Clawson DL (1985) Harvest security and intraspecific diversity in traditional tropical agriculture. Econ Bot 39:56-67

de Schutter O (2010) Report submitted by the Special Rapporteur on the right to food. UN General Assembly. Human Rights Council Sixteenth Session, Agenda item 3 A/HRC/16/49

Dorward A (1999) Farm size and productivity in Malawian smallholder agriculture. J Dev Stud 35:141-161

ETC Group (2009) Who will feed us? Questions for the food and climate crisis. ETC Group Comunique \#102

Ferguson BG, Morales H (2010) Latin American agroecologists build a powerful scientific and social movement. J Sustain Agric 34:339-341

Funes F, García L, Bourque M, Pérez N, Rosset P (eds) (2002) Sustainable agriculture and resistance: transforming food production in Cuba. Food First Books, Oakland

Funes-Monzote FR (2009) Agricultura con futuro: la alternativa agroecologica para Cuba. Estación Experimental Indio Hatuey, Matanzas

Funes-Monzote FR, Monzote M, Lantinga EA, Ter Braak CJF, Sánchez JE, Van Keulen H (2009) Agro-ecological indicators (AEIs) for dairy and mixed farming systems classification: identifying alternatives for the Cuban livestock sector. J Sustain Agric 33(4):435-460

Funes-Monzote FR, Martín GJ, Suárez J, Blanco D, Reyes F, Cepero L, Rivero JL, Rodríguez E, Savran V, del Valle Y, Cala M, Vigil MC, Sotolongo JA, Boillat S, Sánchez JE (2011) Evaluación inicial de sistemas integrados para la producción de alimentos y energía en Cuba. Pastos y Forrajes (forthcoming)

Gliessman SR (1998) Agroecology: ecological process in sustainable agriculture. Ann Arbor Press, Michigan

Holt-Gimenez E (2006) Campesino a Campesino: voices from Latin America's Farmer to Farmer Movement for Sustainable Agriculture. Oakland: Food First Books, Oakland

Holt-Gimenez E, Patel R (2009) Food rebellions: the real story of the world food crisis and what we can do about it. Fahumu Books and Grassroots International, Oxford

IAASTD (International Assessment of Agricultural Knowledge, Science and Technology for Development) (2009) Agriculture at a Crossroads. In: International Assessment of Agricultural Knowledge, Science and Technology for Development Global Report, Island Press, Washington, D.C.

Isakson SR (2009) No hay ganancia en la milpa: the agrarian question, food sovereignty, and the on-farm conservation of agrobiodiversity in the Guatemalan highlands. J Peasant Stud 36(4):725-759
Koohafkan P, Altieri MA (2010) Globally important agricultural heritage systems: a legacy for the future. UN-FAO, Rome

Koont S (2009) The urban agriculture in Havana. Mon Rev 60(1):63-72

Machin-Sosa B, Roque-Jaime AM, Avila-Lozano DR, Rosset P (2010) Revolución Agroecológica: el Movimiento de Campesino a Campesino de la ANAP en Cuba. ANAP, La Habana

Owenya MZ, Mariki ML, Kienzle J, Friedrich T, Kassam A (2011) Conservation agriculture (CA) in Tanzania: the case of Mwangaza B CA farmer field school (FFS), Rothia Village, Karatu District. Int J Agric Sustain 9:145-152

Perfecto I, Vandermeer J, Wright A (2009) Nature's matrix: linking agriculture, conservation and food sovereignty. Earthscan, London

Petersen P, Tardin JM, Marochi F (1999) Participatory development of notillage systems without herbicides for family farming; the experience of the Center-South region of Paraná. In: Environment, development and sustainability. Dordrecht, Kluwer Academic Publishers (special issue on Sustainable Agriculture)

Philpott SM et al (2009) A multiscale assessment of hurricane impacts on agricultural landscapes based on land use and topographic features. Agric Ecosyst Environ 128:12-20

Pimentel D, Pimentel M (1979) Food, Energy and Society. Edward Arnold, London

Pretty JN, Morrison JIL, Hine RE (2003) Reducing food poverty by increasing agricultural sustainability in the development countries. Agric Ecosyst Environ 95:217-234

Pretty J, Toulmin C, Williams S (2011) Sustainable intensification in African Agriculture. Int J Sustain Agric 9:5-24

Rakotondramanana (2011) http://www.ruralforum.info/images/sesiones/ 6-madagascar.pdf

Reij CP, Smaling EMA (2008) Analyzing successes in agriculture and land management in Sub-Saharan Africa: is macro-level gloom obscuring positive micro-level change? Land Use Policy 25:410 420

Ríos H, Vargas D, Funes-Monzote FR (2011) Innovación agroecológica, adaptación y mitigación del cambio climático. INCA, Havana

Rosset PM (1999) Small is bountiful. Ecologist 29:2-7

Rosset PM, Machín-Sosa B, Roque-Jaime AM, Avila-Lozano DR (2011) The Campesino-to-Campesino agroecology movement of ANAP in Cuba. J Peasant Stud 38:161-191

Sanders WT (1957) Tierra y Agua: a study of the ecological factors in the development of Meso-American Civilizations. Ph.D Dissertation, Harvard University

Toledo VM, Barrera-Bassols N (2009) La Memoria Biocultural: la importancia ecológica de las sabidurías tradicionales. ICARIA Editorial, Barcelona

Toledo VM, Carabias J, Mapes C, Toledo C (1985) Ecología y Autosuficiencia Alimentaria. Siglo Veintiuno Editores, Mexico

Uphoff N (2002) Agroecological innovations: increasing food production with participatory development. Earthscan, London

Varela Pérez J (2011) Campesinos fieles a su tradición. Entrevista a Orlando Lugo Fonte, presidente de la Asociación Nacional de Agricultores Pequeños (ANAP). Granma newsletter, Havana, 13 May

Vía Campesina (2010) http://viacampesina.org/downloads/pdf/en/ paper6-EN-FINAL.pdf

Wezel A, Soldat V (2009) A quantitative and qualitative historical analysis of the scientific discipline of agroecology. Int J Agric Sustain 7(1):3-18

Wezel A, Bellon S, Doré T, Francis C, Vallod D, David C (2009) Agroecology as a science, a movement, and a practice. Agron Sustain Dev 29(4):503-515

Wilken GC (1987) Good farmers: traditional agricultural resource management in Mexico and Guatemala. University of California Press, Berkeley

World Agroforestry Center (2009) Agroforestry innovations multiply crop yields in Africa. http://www.northsouth.ethz.ch/news/past events/past_events_zil/annualconference06/posterexhibition/Place.pdf 